Available Online at: http://ejournal.upbatam.ac.id/index.php/jim

\title{
THE IMPACT OF INSTAGRAM MARKETING ADOPTION TOWARDS CONSUMER PURCHASE DECISION ON FASHION
}

\author{
Daniel Cassa Augustinus ${ }^{1}$, Agnes ${ }^{2}$ \\ Universitas Pelita Harapan

\section{daniel.augustinus@uph.edu}

\begin{abstract}
The purpose of this research is to analyse promotion and Affiliate marketing in boosting room sales in nonnetworked hotel guests. In carrying out operations the hotel can use social media to conduct promotional activities. By doing this marketing strategy the hotel will get a better spotlight from users because based on the number of online travel users with the help of social media is the highest in Southeast Asia to the present. Of course in its implementation using direct channel as a business role model, the role of online travel agency to make room booking with price promotion with profit margin favorable for both parties. In the implementation of online travel agents have a risk when not able to sell the package on the prospective visitors of the hotel. We use quantitative explanatory research models using accidental sampling at 60 non-network hotels in Batam is used as a respondent scattered in Batam city. The results obtained from two supporting variables namely promotion and affiliate Marketing showed positive results. The test results showed that nonnetwork hotel promotion and business affiliations from online travel agencies played an important role in the hotel room sales assessment process.
\end{abstract}

Keywords: Instagram, Social Networking Sites, Consumer Purchase Decision, Fashion 


\section{INTRODUCTION}

The world has been globalized with the advent of technology and the ways of communications and sharing information has been revolutionalized completely. Social networking sites has been emerged and transformed the world, bringing the world and its people closer. By having connected to the social networking sites, the activities, behaviours and practices among groups of people who gather online could share information through various social media platform.

Over the last decade, social media which is part of social networking sites has become more effective in marketing tool, it is not only help to market products and services but also provides many opportunities to marketers to create new brand awareness to consumers. Social media has been considered as one of the most effective and interactive tools to increase the consumer purchase decisions. Social media consists of several online platforms that might be useful for consumers to obtain informations, profiles, observations, and even media itself to connect, interact, and communicates to the other online users from all across the world. Even groups of people that never meet in the physical world but they are still able to affect behaviour including purchasing decision.

One of the industry that is considered to be benefited for using the social media platforms is Fashion. According to (Carranza, 2015), social media is an incredibly valuable asset to the fashion industry because of the lightening-fast speed at which content travels on Facebook, Pinterest, and Instagram, which new styles can be shared with millions of people in a matter of seconds. From another point of view, fashion brands find social media to be a very powerful research tool as they use it to find out what styles followers enjoy and what they are wearing (Carranza, 2015). When talking about social media for fashion, it refers to the social networking sites and other social media platforms for fashion industries or marketers to connect and influence consumers decision to purchase products or services using the latest social networking technology.

One of the example of social media platform which has been booming nowadays is Instagram. Instagram was a free, online photo sharing application, and social networks platform that was acquired by Facebook in
2012. Instagram allows users to edit and upload photos and short videos through mobile apps. Users can add caption to each of their posts and use hash tags and location-based geo tags to index the posts and make them searchable by other users within the app. Each post by a user appears on their followers' Instagram feeds and can also be viewed by the public when tagged using hash tags or geo tags. Users also have the option of making their profile private so that only their followers can view their posts. As with other social networking platforms, Instagram users can like, comment on and bookmark others' posts, as well as send private messages to their friends via the Instagram Direct feature. Photos can be shared on one or several other social mediasites including Twitter, Facebook and Tumblr with a single click.

Nowadays, Instagram is not only a tool for individuals, but also for businesses. The photo-sharing app offers companies the opportunity to start a free business account to promote their brand and products. Companies with business accounts have access to free engagement and impression metrics. Currently, Instagram has been a social media platform that allows fashion marketers to market their products, not only that, it also creates a muse among the fashionista. This will simply create consumer's desire to purchase products from the media platforms. By taking a look on the instagram profile, product pictures, and the details of the products, and followers consumers may be attracted to do a purchase from it. Another example of social media platform which is not less important is Facebook.

Previously Facebook was a popular free social networking website that allows registered users to create profiles, upload photos and videos, send messages and keep in touch with friends, family and colleagues. The site which is available in 37 different languages includes public features such as market place, groups, events, pages and presence technology. Through Facebook, people can get diversity of choices and options to purchase towards fashion brands and quality. Instagram who had been acquitted by Facebook, work differently from Facebook. Instagram is about capturing moments, they use to engage with customers. People do not open Instagram to find out their company's business hours. That is what makes 


\section{Terakreditasi Nasional}

\section{Available Online at: http://ejournal.upbatam.ac.id/index.php/jim}

Instagram so effective in building brand and gaining popularity, because Instagram is more focus on mobile users and more visuals. It naturally lends itself to getting content spread. Therefore, it has become more important runaway for the fashion industry.

Social networking sites have the power which can influence consumer purchase decision towards fashion. Everyday people buy things which are relevant to their needs where at the same time they are making a purchase decision. Fashion or clothing is one of the most thing that people may buy through social networking sites or social media platforms. Consumers purchase decisions are influenced by personal and environmental factors. Generally social networks such as social media who own the power over the consumers can affect consumer's purchase decision. The communication that flows between fashion to its consumers is considered to be two-way communication, where they can interact each other, sharing informations, comments, feedback, and rates that can help consumers for purchasing decision in different ways.

Connecting through social networking sites using social media platforms like Instagram and Facebook have become more effective in marketing tool, it is not only help to market products and services but also provides many opportunities to marketers to create new brand awareness to consumers in Medan. One of the industries which can be considered to be benefited from using social media platform is fashion. Instagram is one of social media platform that has been booming nowadays. It was a free, online photo sharing application, and social networks platform that was acquired by Facebook in 2012. These days, Instagram is not a tool used by individuals, but also for businesses to create awareness and engagement with consumers.

Not only creating awareness and engagement, but Instagram and Facebook helps fashion marketers to market their products and creates a muse among fashionista. This approach will give impact on consumer purchase decision as well. The power of social networking sites can possibly give an influence towards consumers to purchase products or services.

Moreover, this research will also try to understand the potential of social networking sites in increasing the consumer purchase decision towards fashion. Related to the research question above, the writer would like to propose hypothesis as :

Hypothesis

$\mathrm{H}_{0} \quad$ : Instagram does not give an impact towards fashion consumers purchase decision in Medan.

$\mathrm{H}_{1} \quad$ : Instagram gives an impact towards fashion consumers purchase decision in Medan.

\section{METHODOLOGY}

In order to see the general picture of the impact of social networking sites towards fashion consumer purchase decision which will be elaborated in further sub-chapters, hypothesis and the testing of hypothesis, the method used to conduct this research will be in quantitative with survey research being the approach. Nazeer (2017) stated that this survey method is used to gather the quantitative data from a large representative but assorted population. Because samples of individuals are used in the survey, it is referred to as sample surveys, with the participants responding to a series of questions in the survey by the means of self-report.

Population is a whole; it is every member in a group, the opposite of sample, which is a fraction or percentage of a group (Stephanie, 2013). As this research focus on the consumer purchase decision in Medan, therefore the population is every social media users in Medan.

Sample is a selection respondents chosen in such a way that they represent the total population as good as possible (Dessel, 2013). Sample size is the amount of consumers in target that will be researched. According Rose, Spinks \& Canhoto (2015), the formula to calculate the sample based on the sample required to estimate a proportion with an approximate $90 \%$ confidence level shown below:

Where $\mathrm{nr}=$ required sample size, $\mathrm{p}=$ proportion of the population having the characteristic, $\mathrm{q}=$ $1-p$, and $d=$ the degree of precision. The proportion of the population (p) may be known from prior research or other sources; or if it is unknown then use $\mathrm{p}=0.5$ which assume maximum heterogeneity (i.e a 50/50 split). The degree of precision (d) is the margin error that is acceptable. 


\section{Available Online at: http://ejournal.upbatam.ac.id/index.php/jim}

Since there is no data are available on the proportion, the worst case scenario which can be take is to set $\mathrm{p}=0.5$ (and therefore $\mathrm{q}=1-0.5$ $=0.5$ ). Accepting a margin error of $10 \%$, thus to determine the minimum sample size that can be applied to this formula:

The final sample size for this research is 100. The sampling type will be non probability sampling, where samples are not used very often in quantitative medical social research surveys, but it is used increasingly in market research and commissioned studies.

The method to choose respondents for this research is using convenience sampling that relies on data collection from population members who are conveniently available to participate in the research or study (Dudovskiy, 2012). This sampling method is used due to the researcher's limited time and resources. Dudovskiy (2012) stated that convenience sampling technique may prove to be effective during exploration stage of the research area, and when conducting pilot data collection in order to identify and address shortcomings associated with questionnaires design.

There are two types of data used in this research, which are Primary and Secondary Data. Primary data refer to the information obtained firsthand by the researcher on the variable interest for the specific purpose of the research, where the primary resources are individuals, focus groups, panels of respondents set up by researcher and from whom opinions may be sought on specific issues from time to time (Sekaran, 2003). To collect the necessary data for this research, a series of questions, in the form of online survey or questionnaire, will be distributed to 100 social media users (mostly Instagram users) in Medan to be filled in regarding to the usability of social networking sites especially Instagram variables and consumer purchase decision variables. Those social media users as respondents will fill the questionnaire or survey by themselves.

The supporting information gathered from sources that already existing for a research is called secondary data. As presented by Sekaran (2003), it has been stated that data can be obtained by secondary resources which are from company records or archives, government publications, industry analyses offered by media, websites, and the internet and so on. In this research, the secondary data that we are going to find is like process of how to do an online purchasing through Instagram, or any other necessary data that will be discussed in the form of observation, literature reviews, from numerous books or ebooks, websites, or published research journals.

The operational variable is the statement of the specific dimensions and elements through which variables will become measureable. The operational variables are below

Variable X : The usability of Social Networking Sites (SNS) as the independent variable which will influence the dependent variable. Especially Instagram (social media platform), as the moderator variable which will help the independent variable in influencing dependent variable. However, without this variable, the independent variable still can influence the dependent variable.

Variable Y : Consumers Purchase Decision as the dependent variable which will be the main focus on this research that will be influenced by independent variable.

For the purpose of measuring the interval scale, 10-point Likert Scale will be applied. 10-point Likert scale is psychological measurement device that is used to gauge attitudes, values and opinions. According to Hopper (2014), he found out that specifically 0-10 scales with 5 anchored as midpoint consistently had the smallest amount of data missing. These results were consistent across multiple surveys in both political and economic domains and across items which asked the respondents to make favorability ratings and items that asked for approval judgements (Hopper, 2014). The questionnaire has ten statements that must be rated from 1-10 which are 'not at all likely', 'neither likely no unlikely', and 'extremely likely'. It functions by having a person complete a questionnaire that requires them to indicate to extent to which they agree or disagree with a series of statements.

Table 1 The Operationalisation of Research Variables

Variable

Dimension

Definition
Indicator

Measurement 


\section{Terakreditasi Nasional}

Available Online at: http://ejournal.upbatam.ac.id/index.php/jim

\begin{tabular}{|c|c|c|c|c|}
\hline $\begin{array}{l}\text { Screening } \\
\text { questions }\end{array}$ & & & $\begin{array}{l}\text { - Are you a } \\
\text { resident of Medan? } \\
\text { - Do you } \\
\text { consider yourself to be } \\
\text { a social media user? } \\
\text { - What is your } \\
\text { gender? } \\
\text { you? How old are }\end{array}$ & Nominal \\
\hline \multirow{6}{*}{$\begin{array}{c}\text { usability of } \\
\text { Social } \\
\text { Networking } \\
\text { Sites (SNS)The }\end{array}$} & Internet & $\begin{array}{l}\text { How many hours } \\
\text { do people spent on } \\
\text { using internet } \\
\text { everyday }\end{array}$ & $\begin{array}{l}\text { Numbers of hours } \\
\text { spent _- }\end{array}$ & Ratio \\
\hline & $\begin{array}{c}\text { Purpose of } \\
\text { using Internet }\end{array}$ & $\begin{array}{l}\text { People's purpose } \\
\text { why they use } \\
\text { internet }\end{array}$ & $\begin{array}{l}\text { Browsing, social } \\
\text { networking (chatting), } \\
\text { online shopping, } \\
\text { others. }\end{array}$ & Nominal \\
\hline & $\begin{array}{l}\text { Media / } \\
\text { Platform }\end{array}$ & $\begin{array}{l}\text { Would you likely } \\
\text { to use Instagram } \\
\text { as social media } \\
\text { platform }\end{array}$ & Yes or No & Nominal \\
\hline & $\begin{array}{l}\text { Purchase } \\
\text { Experiences }\end{array}$ & $\begin{array}{l}\text { How many times } \\
\text { done online } \\
\text { purchasing } \\
\text { through Instagram } \\
\text { before } \\
\end{array}$ & $\begin{array}{l}\text { Numbers of how many } \\
\text { times done purchasing } \\
\text { through Instagram }\end{array}$ & Ratio \\
\hline & $\begin{array}{l}\text { Factors that } \\
\text { impact } \\
\text { shopping }\end{array}$ & $\begin{array}{l}\text { What kind of } \\
\text { factors that } \\
\text { influence people } \\
\text { to shop through } \\
\text { Instagram }\end{array}$ & $\begin{array}{l}\text { Cheap price, Well- } \\
\text { Known Brand, Free } \\
\text { Shipping, Great } \\
\text { Reviews, More } \\
\text { Followers, Product } \\
\text { Availability }\end{array}$ & Nominal \\
\hline & $\begin{array}{l}\text { Future } \\
\text { Purchase }\end{array}$ & $\begin{array}{l}\text { People would like } \\
\text { to shop through } \\
\text { Instagram in } \\
\text { future }\end{array}$ & $\begin{array}{l}\text { Would you like to } \\
\text { purchase product } \\
\text { through Instagram in } \\
\text { the future? }\end{array}$ & Nominal \\
\hline & $\begin{array}{c}\text { Social Media } \\
\text { Engagement }\end{array}$ & $\begin{array}{l}\text { Engagement } \\
\text { between Instagram } \\
\text { and consumer } \\
\text { through likes and } \\
\text { comments }\end{array}$ & $\begin{array}{l}\text { - I would likely } \\
\text { to buy product from } \\
\text { Instagram stores that } \\
\text { have lots of likes } \\
\text { - I would likely } \\
\text { to buy product through } \\
\text { Instagram stores which } \\
\text { have lots of positive } \\
\text { comments }\end{array}$ & Interval \\
\hline & $\begin{array}{l}\text { Engaging } \\
\text { Hashtags }\end{array}$ & $\begin{array}{c}\text { Engagement } \\
\text { created between } \\
\text { consumer and } \\
\text { Instagram through } \\
\text { hashtags }\end{array}$ & $\begin{array}{l}\text { - I would likely } \\
\text { use keywords in a form } \\
\text { of hashtags to buy } \\
\text { product through } \\
\text { Instagram stores } \\
\text { (ex. \#wintercoat) }\end{array}$ & Interval \\
\hline & $\begin{array}{l}\text { Engagement } \\
\text { per Followers }\end{array}$ & $\begin{array}{c}\text { Engagement } \\
\text { created between } \\
\text { Instagram stores }\end{array}$ & $\begin{array}{l}\text { I I would likely } \\
\text { to buy products } \\
\text { through Instagram }\end{array}$ & Interval \\
\hline
\end{tabular}


Available Online at: http://ejournal.upbatam.ac.id/index.php/jim

\begin{tabular}{|c|c|c|c|c|}
\hline \multirow{5}{*}{$\begin{array}{l}\text { The usability of } \\
\text { Instagram }\end{array}$} & & $\begin{array}{l}\text { and consumer } \\
\text { through number of } \\
\text { followers }\end{array}$ & $\begin{array}{l}\text { stores which have lots } \\
\text { of followers on it. }\end{array}$ & \\
\hline & Product Price & $\begin{array}{l}\text { Factors that } \\
\text { influence an } \\
\text { individual's } \\
\text { decision to do a } \\
\text { purchase based on } \\
\text { the price of the } \\
\text { product }\end{array}$ & $\begin{array}{l}\text { I would like to } \\
\text { buy this product } \\
\text { through Instagram } \\
\text { stores because it is } \\
\text { worth with the quality } \\
\text { I would like to } \\
\text { buy this product } \\
\text { through Instagram } \\
\text { stores because it is } \\
\text { cheap }\end{array}$ & Interval \\
\hline & Reviews & $\begin{array}{l}\text { Factors that } \\
\text { influence an } \\
\text { individual's } \\
\text { decision to do a } \\
\text { purchase based on } \\
\text { reviews from } \\
\text { family, peers or } \\
\text { other consumers }\end{array}$ & $\begin{array}{l}\text { I buy this } \\
\text { product because my } \\
\text { family or friends } \\
\text { suggest it to me } \\
\text { - I buy this } \\
\text { product because many } \\
\text { social influencers give } \\
\text { a good reviews on it }\end{array}$ & Interval \\
\hline & $\begin{array}{l}\text { Store's } \\
\text { Presence on } \\
\text { Instagram }\end{array}$ & $\begin{array}{l}\text { Store's presence } \\
\text { on Instagram will } \\
\text { likely to influence } \\
\text { and create } \\
\text { awareness to } \\
\text { consumer through } \\
\text { its content and } \\
\text { post feed. }\end{array}$ & $\begin{array}{l}\text { I would likely } \\
\text { to buy product through } \\
\text { Instagram stores which } \\
\text { have an eye catching } \\
\text { contents. } \\
\text { - I would likely } \\
\text { to buy product through } \\
\text { Instagram stores which } \\
\text { have lots of post feeds } \\
\text { to be seen. }\end{array}$ & Interval \\
\hline & $\begin{array}{l}\text { Advertising } \\
\text { on Social } \\
\text { Media }\end{array}$ & $\begin{array}{l}\text { Advertising that } \\
\text { will likely to } \\
\text { influence } \\
\text { consumer } \\
\text { purchase decision } \\
\text { by placing ads on } \\
\text { Instagram }\end{array}$ & $\begin{array}{l}\text { I would likely } \\
\text { to buy product which } \\
\text { has been advertised as } \\
\text { ads on Instagram. }\end{array}$ & Interval \\
\hline
\end{tabular}

Table 2 The Operationsalisation of Research Variables (continue)

\begin{tabular}{|c|c|c|c|c|}
\hline Variable & Dimension & Definition & Indicator & Measurement \\
\hline \multirow[t]{2}{*}{$\begin{array}{l}\text { Consumer } \\
\text { Purchase } \\
\text { Decision }\end{array}$} & $\begin{array}{l}\text { Psychological } \\
\text { Factors }\end{array}$ & $\begin{array}{l}\text { Factors that } \\
\text { influence an } \\
\text { individual's } \\
\text { decision to do a } \\
\text { purchase based on } \\
\text { their needs, } \\
\text { influence and } \\
\text { motivation }\end{array}$ & $\begin{array}{l}\text { I need this } \\
\text { product because I } \\
\text { don't have it } \\
\text { - My friend told } \\
\text { us that this product is } \\
\text { good } \\
\text { product to finish my } \\
\text { work }\end{array}$ & Interval \\
\hline & $\begin{array}{l}\text { Personal } \\
\text { Factors }\end{array}$ & $\begin{array}{l}\text { Factors that } \\
\text { influence an }\end{array}$ & $\begin{array}{l}\text { This product } \\
\text { is belong to me }\end{array}$ & Interval \\
\hline
\end{tabular}




\section{Terakreditasi Nasional}

Available Online at: http://ejournal.upbatam.ac.id/index.php/jim

\begin{tabular}{|c|c|c|c|}
\hline & $\begin{array}{c}\text { individual's } \\
\text { decision to do a } \\
\text { purchase based on } \\
\text { characteristics, } \\
\text { interests, beliefs, } \\
\text { and attitudes. }\end{array}$ & $\begin{array}{l}\text { I buy this } \\
\text { product because } \\
\text { everyone says this is a } \\
\text { best-seller product. } \\
\text { - I buy this } \\
\text { product because I love } \\
\text { it. }\end{array}$ & \\
\hline $\begin{array}{c}\text { Cultural } \\
\text { Factors }\end{array}$ & $\begin{array}{l}\text { Factors that } \\
\text { influence an } \\
\text { individual's } \\
\text { decision to do a } \\
\text { purchase based on } \\
\text { religion, status } \\
\text { and gender. }\end{array}$ & $\begin{array}{l}\text { I buy this } \\
\text { product because I can } \\
\text { have it } \\
\text { product because I'm a } \\
\text { woman/man }\end{array}$ & Interval \\
\hline Social Factors & $\begin{array}{c}\text { Factors that } \\
\text { influence an } \\
\text { individual's } \\
\text { decision to do a } \\
\text { purchase based on } \\
\text { role in the } \\
\text { society, reference } \\
\text { group, and status. }\end{array}$ & $\begin{array}{l}\text { I buy this } \\
\text { product because I can } \\
\text { afford to buy it. } \\
\text { - I buy this } \\
\text { product because my } \\
\text { friends recommend me } \\
\text { about it. }\end{array}$ & Interval \\
\hline $\begin{array}{l}\text { Economic } \\
\text { Factors }\end{array}$ & $\begin{array}{c}\text { Factors that } \\
\text { influence an } \\
\text { individual's } \\
\text { decision to do a } \\
\text { purchase based on } \\
\text { wealth and } \\
\text { income levels. }\end{array}$ & $\begin{array}{l}\text { I buy this } \\
\text { product because it is } \\
\text { cheap } \\
\text { - I buy this } \\
\text { product because it is a } \\
\text { well-known store } \\
\text { brand }\end{array}$ & Interval \\
\hline
\end{tabular}

Source: Prepared by Writer (2018)

Validity test shows how well an instrument that is developed measures the particular concept it is intended to measure (Sekaran, 2003). In other words, validity is concerned with whether the right concept is measured, reliability with stability and consistency of measurement. In this research, the validity test is based on comparison of model predictions and coefficients with theory, collection of new data to check model prediction, comparison of results with theoretical model calculations, and data splitting or cross-validation in which a portion of the data is used to estimate the model coefficients, and the remainder of the data is used to measure the prediction accuracy of the model (Snee, 2012). The factor validity test in this research will be calculated with the SPSS 21 software. As presented by adminspssstatistik (2016), to measure whether the indicator of variables is valid or not, just compare the $r_{\text {count }}$ with $r_{\text {table }}$ with the requirements of:
1. If $r_{\text {count }} \geq r_{\text {table }}$, then $\mathrm{H}_{0}$ is rejected, $\mathrm{H}_{1}$ is accepted (valid)

2. If $r_{\text {count }}<r_{\text {table }}$, then $\mathrm{H}_{0}$ is accepted, $\mathrm{H}_{1}$ is rejected (invalid)

Reliability is the degree to which a measure is an error free and then ensures consistent measurement across time and across various items in the instrument (Sekaran, 2003). The reliability test conducted in this research is to measure the consistency and the reliability of the questions in the questionnaire towards variables. To measure the reliability, a reliability analysis, the Cronbach's Alpha test will be used in this research. According to Sekaran (2003), a reliability coefficient indicates how well the items in a set are positively correlated to one another. The closer Cronbach's alpha is to 1, the higher the internal consistency reliability (Sekaran, 2003). The Cronbach's Alpha is measured using SPSS 17 software. Meanwhile, based on Wahyuni (2014), the requirement whether the variable is reliable on each other can be seen if: 
Available Online at: http://ejournal.upbatam.ac.id/index.php/jim

1. Cronbach's Alpha $>0.9$ means the perfect reliability

2. Cronbach's Alpha 0.7 - 0.9 means good reliability

3. Cronbach's Alpha $0.5-0.7$ means moderate reliability

4. Cronbach's Alpha $<0.5$ means low realibility

5. If Cronbach's Alpha is low, means there maybe one or some items are not reliable.

To measure whether the dependent variable in related to the independent variable, Pearson's correlation is used. Correlation coefficients are used in statistics to measure how strong relationship is between two variables where return a value between -1 and 1, where 1 indicates a strong positive relationship, -1 indicates a strong negative relationship, and 0 indicates no relationship at all. (Statistic How To, 2018) stated that Pearson's correlation is commonly used in linear regression with the formula of

$$
r=\frac{n\left(\sum x y\right)-\left(\sum x\right)\left(\sum y\right)}{\sqrt{\left[n \Sigma x^{2}-(\Sigma x)^{2}\right]\left[n \sum y^{2}-\left(\sum y\right)^{2}\right]}}
$$

Gambar 1 Manifested Variabel.

Where:

Where: $\begin{array}{ll}\mathrm{n} & =\text { number of pairs of scores } \\ \text { pairs scores } & \begin{array}{ll}\sum x y & =\text { sum of the product of } \\ \sum x & =\text { sum of } x \text { scores } \\ \sum y & =\text { sum of } y \text { scores } \\ \sum x^{2} & =\text { sum of squared } x \text { scores } \\ y^{2} & =\text { sum of squared } y \text { scores }\end{array}\end{array}$

The hypothesis testing or methods that will be used in this research is regression analysis. Regression analysis is a mathematical measure of the average relationship between two or more variables in terms of the original unit of the data (Gallo, 2015). In regression, the variable corresponding to cause is taken as independent variable and the variable corresponding to effect is taken as dependent variable (Srinagesh, 2013). According to Srinagesh (2013), regression equation is $\mathbf{y}=\mathbf{a}_{\mathbf{0}}$ $+\mathbf{b}_{1} \mathbf{X}$, where $\mathrm{y}$ is the independent variable, $\mathrm{a}_{0}$ is constant, $b_{1}$ is slope of the regression line, $X$ is the independent variable. In this research, a two-tailed hypothesis test will be used to test the statistical significance in one direction and in the other direction, using a significance level of 0.1 (idre, 2017). This means that 0.05 is in each tail of the distribution will be the test statistic (idre, 2017).

In order to see whether an independent variable is influencing the dependent variable, t-test statistic method is used in this research. As presented by Ghozali (2013 : 98), hypothesis testing using t-test method is aim to determine whether an independent variable individually explains the variance in dependent variable. The null hypothesis $\left(H_{0}\right)$ which will be tested is a parameter $(b i)$ equals to zero. The form of the test is listed below:

1. $H_{0}: b_{1}, b_{2}=0$ (the usability of Instagram partially does not give an impact towards fashion consumer purchase decision in Medan).

2. $H_{1}: b_{1}, b_{2} \neq 0$ (the usability of Instagram partially gives an impact towards fashion consumer purchase decision in Medan). To decide whether a hypothesis can be accepted or rejected is to compare a value of $t_{\text {count }}$ and $t_{\text {table }}$ with confidence level $90 \%$ and margin of error $10 \%$ with the criteria of $\mathrm{H}_{1}$ will be accepted if $t_{\text {count }}>t_{\text {table }}$ with the $\alpha<0.1$ (Raharjo, 2015).

According to SPSS (2015), linearity test aims to identify and measure whether the relationship between independent variable and dependent variable is linear or not. The linearity test is a requirement in the correlation and linear regression analysis. Good research in the regression model should have a linear relationship between independent variable and dependent variable. The decision making process in the linearity test is:

1. If the value of significance from linearity

$<0.1$, then the relationship between the independent variables are linearly dependent.

2. If the value of significance from linearity $>0.1$, then the relationship between independent variables with dependent is not linear.

\section{FINDINGS}

As the variables of this research is the usability of Social Networking Sites: Instagram and consumer purchase decision towards fashion in Medan, therefore the research objects are youngsters who are social media users. Long before it become the commercialized mass information and was accessible to the general public today, social networking sites (social media) were nothing back then. Today, social media has been very popular and needed 


\section{Terakreditasi Nasional}

\section{Available Online at: http://ejournal.upbatam.ac.id/index.php/jim}

as human lifestyle. Social media itself is a platform that allows people to interact, communicate, share information in the cyberspace without limitation of time and distance as long as it is connected to the Internet. In the beginning of social media development, it aims for communication between communities with particular purposes. However, its development is no longer limited to social media, but it has developed into a medium of information, communication, interaction, and even a promotion of the digital era and online business.

In 1995 , social web based were established for the first time as Geocities. Geocities is a milestone of millions of other websites in the online world. The site is engaged in rental hosting to store data in the online world to be accessible to many people with the Internet. From 1997 to 1999, it created the first community social media with the name of sixdegree and classmates. While on 2002, Friendster was born which is quite popular with a wider range of users. The technology keep developing more and right in 2010, Instagram was first unleashed. Kevin Systrom and Mike Krieger, the founder of Instagram, established the photo-sharing platform that would soon become a selfie-filled, multi-billion-dollar beast used by 500 million people. Instagram itself is a social media platform which is used by the users to take pictures, post their pictures, installing digital filter, and share it to other social media platforms including Instagram itself. However, other small businesses and advertisers, who may not be looking for worldwide virality, are turning to the platform becoming a crowded space. As a result, Instagram has been trying to become a platform which is possible for businesses and advertisers.

Over the years, a new market has formed where brands team up with individual influencers to form a deal. Popular fashion and food accounts began to see future standalone businesses by doing this. Based on TribunMedan.com (2016), Instagram users in Medan surprisingly reach around 600 million active users in 2016; it is two times larger than the previous year which is 300 million active users. Thus, it can be said that Instagram would be the most powerful tools in fashion because compared to other social media platforms, the viral nature of Instagram is much more potent in spreading a commercial message when it comes to fashion (Georgiou, 2016). Currently, Instagram has also changed the way fashion is reported, consumed and shared. People would rather spend their time by doing online shopping than shop in a retail store. According to my observation in using hashtag '\#fashionmedan' to find store-seller in Instagram, it pops out 'top' 16 hashtags and 30 store-sellers name comes out while using the same hashtags with the name below:

Table 3 Tags in Instagram

\begin{tabular}{|c|c|c|c|}
\hline \multicolumn{4}{|c|}{ Tags } \\
\hline \#fashionmedan & $\begin{array}{c}\text { \#fashionmedan0 } \\
1\end{array}$ & \#fashionmedan_top & \#fashionmedan9 \\
\hline \#fashionmedanmurah & $\begin{array}{c}\text { \#fashionmedan8 } \\
6\end{array}$ & \#fashionmedan2017 & \#fashionmedan7 \\
\hline \#fashionmedanstyle & $\begin{array}{c}\text { \#fashionmedan1 } \\
6\end{array}$ & \#fashionmedancantik & \#fashionmedanh \\
\hline \#fashionmedantshirt & $\begin{array}{c}\text { \#fashionmedano } \\
\mathrm{k}\end{array}$ & $\begin{array}{c}\text { \#fashionmedancantikdanmur } \\
\text { ah }\end{array}$ & \#fashionmedanfashionsolo \\
\hline
\end{tabular}

Source: prepared by writer (2018)

Table 4 People in Instagram

\begin{tabular}{|c|c|c|c|c|}
\hline \multicolumn{5}{|c|}{ People } \\
\hline fashionmedan_top & fashionmedan12 & fashionmedan.id & fashion.medan3591 & olshopmedanbwu \\
\hline fashion.medan31 & fashion_medan_top & fashionmedan99 & fashionmedan1 & mn_fashionmedan \\
\hline fashionmedann1 & fashion_medan3050 & butik_fashionmedan & fashion.medan_ & dcollectionmurahmedan \\
\hline fashion_medan & ti_fashionmedan & r_fashionmedan & fashionmedan20 & defri.indah.shop \\
\hline
\end{tabular}




\section{Terakreditasi Nasional}

Available Online at: http://ejournal.upbatam.ac.id/index.php/jim

\begin{tabular}{|c|c|c|c|c|}
\hline medancollection.23 & luxuryfashion_medan & tas_fashionmedan & fashion.medan & radexa_fashionmedan \\
\hline fashionmedan7685 & fashionmedan_murah & $2^{\text {nd }} \_$fashionmedan & fashion_medan3426 & bs.fashionmedan \\
\hline
\end{tabular}

Source: prepared by writer (2018)

As an online shopper, shopping online through Instagram can be said quite simple. As long as the smartphone or computers connected to the internet, people can do an online purchasing through Instagram or other social media platforms. These are the steps in doing online purchasing through Instagram:

Choose a store-seller account through explore or by using hashtags

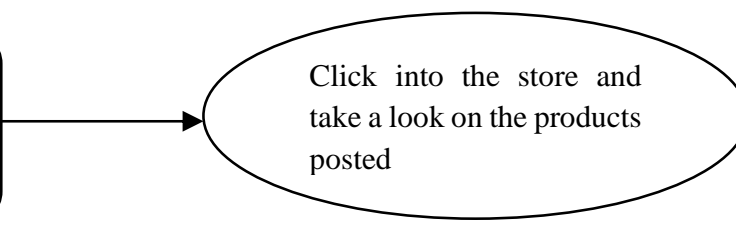

Choose the products that you like

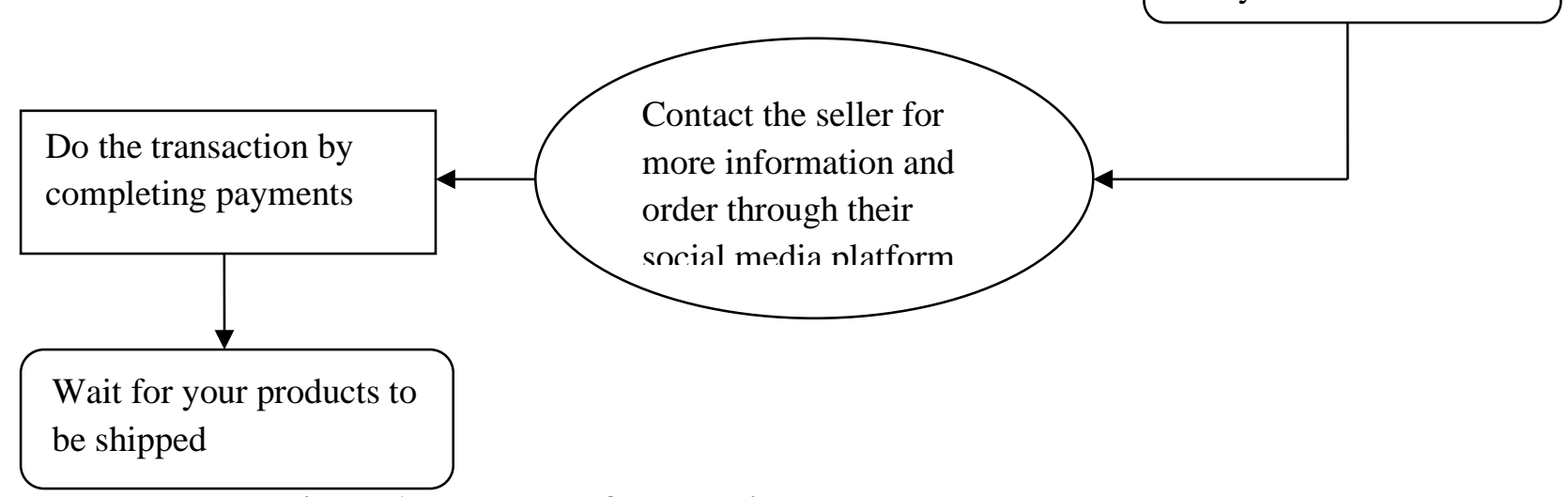

Figure 1 Flowchart of Purchasing Process Through Instagram

Source: Prepared by writer (2018)

So, when someone buy thing from instagram they will get through six steps which are:

1. Choose a store-seller account in Instagram through the pictures which have been posted in 'explore', text the name of the store that you know or you can find it using hashtags.

2. After the store is found, take a look on the product posted

3. Choose the products that you like.

4. Contact the seller about the details, price of the products, and order via Direct Messages, Whatsapp, or Line.

5. Complete the payment which has been asked by the seller.

6. Wait for your product to be shipped into your address.

Because of its great features, Instagram is trying to sell the idea that the application is a place for discovering goods, and this is why a lot of people done their purchasing online through Instagram. According to the results taken from the questionnaires, $37.3 \%$ of the respondents are males and other $62.7 \%$ are females. This indicates that the majority of the respondents are females, because they tend to be the one who purchase fashion quite often.

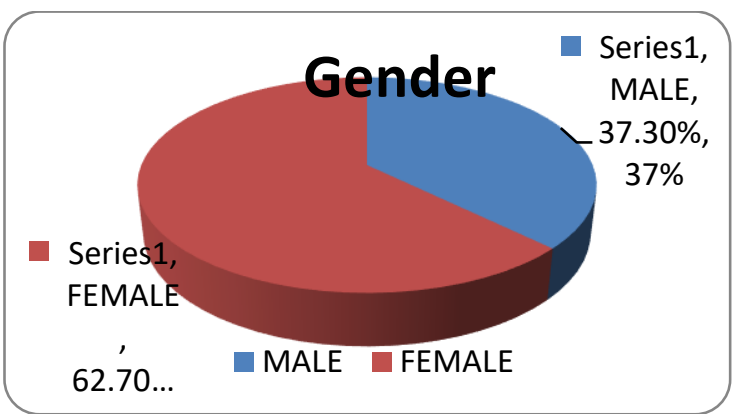

Figure 2 Frequency Distribution of Respondent's Gender

Source: SPSS Output, prepared by writer (2018) 


\section{Available Online at: http://ejournal.upbatam.ac.id/index.php/jim}

According to the results taken from the questionnaires, $100 \%$ of the respondents are living in Medan, Thus, this can be said that user of internet are from Medan

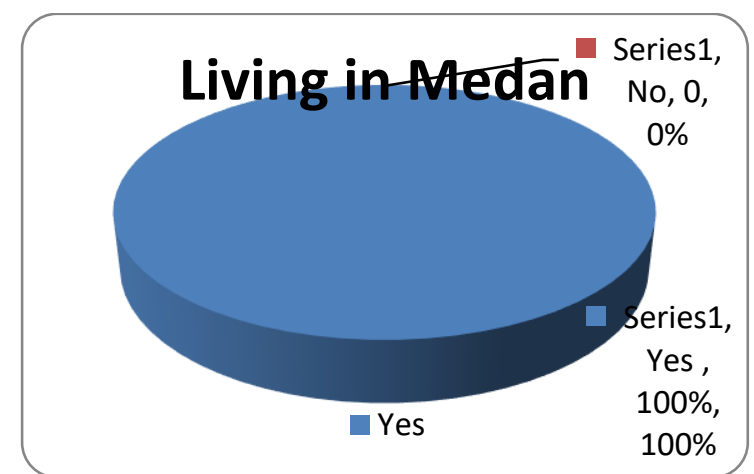

Figure 3 Frequency Distribution of Respondent's Living Based

Source: SPSS Output, prepared by writer (2018) It is

Showed also in the pie chart below that all of the respondents $(100 \%)$ are using Instagram as their social media platform. This indicates that Medanese are Instagram users.
There are $10 \%$ who aged below 20 years old, while there are $88.2 \%$ who aged between 20 to 29 years old; on the other hand, there are only $0.9 \%$ who aged between 30 to 39 years old and $0.9 \%$ who aged above 49 years old. Therefore, youngsters who aged around 20 to 29 years old made up most of the respondents due to their purchasing power as well as their lifestyle in using social media.

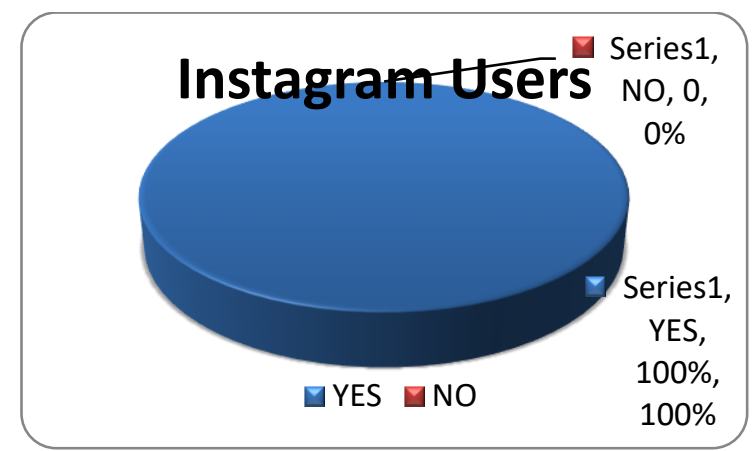

Figure 4 Frequency Distribution of Instagram Users Source: SPSS Output, prepared by writer (2018)

Table 5 Frequency Distribution of Respondent's Age

\begin{tabular}{|ll|l|l|l|l|}
\hline & Frequency & Percent & Valid Percent & Cumulative Percent \\
\hline Valid & $<20$ th & 11 & 10.0 & 10.0 & 10.0 \\
& $>49$ th & 1 & 9 & .9 & 10.9 \\
& $20-29$ th & 97 & 88.2 & 88.2 & 99.1 \\
$30-39$ th & 1 & .9 & .9 & 100.0 \\
Total & 110 & 100.0 & 100.0 & \\
\hline
\end{tabular}

Source:SPSS Output, prepared by writer (2018)

Results taken from the table below, it is showed that most of the respondents spend their time using internet for about 5 to 10 hours in a day $(49.1 \%)$, while there are $32.7 \%$ spend their time using internet below 5 hours in a day, and there are $18.2 \%$ spend their time using internet for more than 10 hours. This indicates that most youngsters or social media users will spend 5 to 10 hours using Internet in a day. 
Available Online at: http://ejournal.upbatam.ac.id/index.php/jim

Table 6 Frequency Distribution of Respondent's Internet Usage

\begin{tabular}{|c|l|l|l|l|}
\hline & & & Valid & Cumulative \\
& Frequency & Percent & Percent & Percent \\
\hline Valid< 5 hrs & 36 & 32.7 & 32.7 & 32.7 \\
$5-10 \mathrm{hrs}$ & 54 & 49.1 & 49.1 & 81.8 \\
$>10 \mathrm{hrs}$ & 20 & 18.2 & 18.2 & 100.0 \\
Total & 110 & 100.0 & 100.0 & \\
\hline
\end{tabular}

Source: SPSS Output, prepared by writer (2018)

From all respondents, there are 7 people (6.4\%) who use internet for browsing, 6 people $(5.5 \%)$ use internet for chatting, 12 people $(10.9 \%)$ use internet for online shopping, 32 people (29.1) use internet for browsing and chatting, 3 people $(2.7 \%)$ use internet for browsing and online shopping, 4 Sadadadada people $(3.6 \%)$ use internet for chatting and online shopping, and 46 people $(41.8 \%)$ use internet for browsing, chatting and online shopping. This indicates that the activities done by most of the respondents are spending their time using internet for browsing, chatting and online shopping.

Figure 7 Frequency Distribution of Active Users

\begin{tabular}{|c|c|c|c|c|c|}
\hline & & Frequency & Percent & Valid Percent & $\begin{array}{c}\text { Cumulative } \\
\text { Percent } \\
\end{array}$ \\
\hline \multirow[t]{8}{*}{ Valid } & Browsing & 7 & 6.4 & 6.4 & 6.4 \\
\hline & Chatting & 6 & 5.5 & 5.5 & 11.8 \\
\hline & Online Shopping & 12 & 10.9 & 10.9 & 22.7 \\
\hline & Browsing and Chatting & 32 & 29.1 & 29.1 & 51.8 \\
\hline & $\begin{array}{l}\text { Browsing and Online } \\
\text { Shopping }\end{array}$ & 3 & 2.7 & 2.7 & 54.5 \\
\hline & $\begin{array}{l}\text { Chatting and Online } \\
\text { Shopping }\end{array}$ & 4 & 3.6 & 3.6 & 58.2 \\
\hline & All & 46 & 41.8 & 41.8 & 100.0 \\
\hline & Total & 110 & 100.0 & 100.0 & \\
\hline
\end{tabular}

Source: SPSS Output, prepared by writer (2018)

Based on the table below, there are $54.5 \%$ of the respondents are actively using Instagram as their main social media platforms, while the other $45.5 \%$ said no. Therefore, Instagram can be considered as the main of social media platforms used by the respondents in this research.

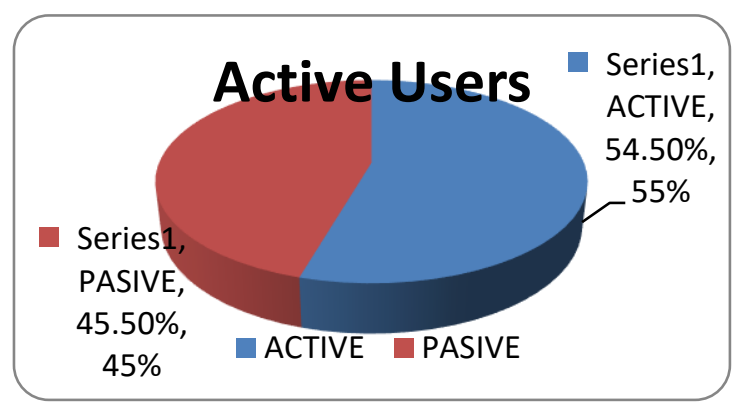

Source: SPSS Output, prepared by writer (2018) 
Available Online at: http://ejournal.upbatam.ac.id/index.php/jim

There are $50.9 \%$ who did online majority of respondents who did online shopping less than 5 times, while there are $24.5 \%$ who did online shopping around 5 to 10 shopping through Instagram are less than 5 times and more than 10 times. As the result, the times

Table 8 Frequency Distribution of Respondent's Shopping Frequency

\begin{tabular}{|c|c|c|c|c|c|}
\hline & & Frequency & Percent & Valid Percent & $\begin{array}{c}\text { Cumulative } \\
\text { Percent }\end{array}$ \\
\hline \multirow[t]{4}{*}{ Valid } & $<5$ times & 56 & 50.9 & 50.9 & 50.9 \\
\hline & 5 - 10 times & 27 & 24.5 & 24.5 & 75.5 \\
\hline & $>10$ times & 27 & 24.5 & 24.5 & 100.0 \\
\hline & Total & 110 & 100.0 & 100.0 & \\
\hline
\end{tabular}

Source: SPSS Output, prepared by writer (2018)

In conjunction to online shopping through Instagram, there are 17 people $(15.5 \%)$ did online shopping due to free shipping and good review, while 2 people (1.8\%) did online shopping due to famous brand and lots of followers, 15 people (13.6\%) did online shopping due to cheap price and product availability, 1 person $(0.9 \%)$ did shopping due to good review and product availability, 4 people (3.6\%) did online shopping due to good review and famous brand, while other 71 people $(64.5 \%)$ did online shopping due to all factors. Thus, based on the results below, all of the factors such as free shipping, good review, famous brand, and lots of followers, product availability and cheap price are the main factors which will affect their purchase decision.

Table 9 Frequency Distribution of Respondent's Purchase Factor

\begin{tabular}{|c|c|c|c|c|c|}
\hline & & Frequency & Percent & Valid Percent & $\begin{array}{l}\text { Cumulative } \\
\text { Percent }\end{array}$ \\
\hline \multirow[t]{7}{*}{ Valid } & $\begin{array}{l}\text { Free Shipping and Good } \\
\text { Review }\end{array}$ & 17 & 15.5 & 15.5 & 15.5 \\
\hline & $\begin{array}{l}\text { Famous Brand and A Lots } \\
\text { of Followers }\end{array}$ & 2 & 1.8 & 1.8 & 17.3 \\
\hline & $\begin{array}{l}\text { Product Availability and } \\
\text { Cheap }\end{array}$ & 15 & 13.6 & 13.6 & 30.9 \\
\hline & $\begin{array}{l}\text { Good Review and Product } \\
\text { Availability }\end{array}$ & 1 & .9 & .9 & 31.8 \\
\hline & $\begin{array}{l}\text { Good Review and Famous } \\
\text { Brand }\end{array}$ & 4 & 3.6 & 3.6 & 35.5 \\
\hline & All & 71 & 64.5 & 64.5 & 100.0 \\
\hline & Total & 110 & 100.0 & 100.0 & \\
\hline
\end{tabular}

Source: SPSS Output, prepared by writer (2018)

Results taken from pie chart below, it indicates that $80 \%$ the majority of respondents (88 people) say "yes" to continue further online purchase, while the other 22 people (20\%) say "no" to do a further online purchase. Hence, it can be said that most of the respondents will do a further purchase through Instagram. 


\author{
Figure 6 Frequency Distribution of \\ Respondent's Further Purchase \\ Source: SPSS Output, prepared by writer \\ (2018)
}

validity and reliability. For the variable "the usability of instagram" and "consumer purchase decision", the validity values for each indicators are shown in the table below.

For the reliability analysis, the Cronbach's Alpha is used, with the results of 0.906 , and 0.937 , for the variable "the usability of instagram", "consumer purchase decision" consecutively.

Table 10 Validity Test of The Usability of Instagram

\begin{tabular}{|c|l|c|c|c|}
\hline No & \multicolumn{1}{|c|}{ Questions } & $r_{\text {count }}$ & $\begin{array}{l}\text { Sig } 2 \\
\text { tailed }\end{array}$ & Conclusion \\
\hline $\mathrm{Q}_{1}$ & $\begin{array}{l}\text { I will buy fashion product from the virtual store } \\
\text { in Instagram who has a lot of "likes" }\end{array}$ & 0.556 & 0.000 & Valid \\
\hline $\mathrm{Q}_{2}$ & $\begin{array}{l}\text { I will buy fashion product from the virtual store } \\
\text { in Instagram who has more comments or } \\
\text { positive reviews from other consumers }\end{array}$ & 0.656 & 0.000 & Valid \\
\hline $\mathrm{Q}_{3}$ & $\begin{array}{l}\text { I will use the keywords in the form of } \\
\text { "hashtags" to find and buy fashion product } \\
\text { from the virtual store in Instagram }\end{array}$ & 0.715 & 0.000 & Valid \\
\hline $\mathrm{Q}_{4}$ & $\begin{array}{l}\text { I will buy fashion product from the virtual store } \\
\text { in Instagram who has a lot of followers }\end{array}$ & 0.702 & 0.000 & Valid \\
\hline $\mathrm{Q}_{5}$ & $\begin{array}{l}\text { I will buy fashion product from the vitual store } \\
\text { in Instagram due to cheaper price }\end{array}$ & 0.854 & 0.000 & Valid \\
\hline $\mathrm{Q}_{6}$ & $\begin{array}{l}\text { I will buy fashion product from the virtual store } \\
\text { in Instagram due to the recommendations from } \\
\text { family and peers }\end{array}$ & 0.701 & 0.000 & Valid \\
\hline $\mathrm{Q}_{7}$ & $\begin{array}{l}\text { I will buy fashion product from the virtual store } \\
\text { in Instagram because many public figure or } \\
\text { social influencer give a great reviews }\end{array}$ & 0.874 & 0.000 & Valid \\
\hline $\mathrm{Q}_{8}$ & $\begin{array}{l}\text { I will buy fashion product from the virtual store } \\
\text { in Instagram who has a great content account }\end{array}$ & 0.887 & 0.000 & Valid \\
\hline $\mathrm{Q}_{9}$ & $\begin{array}{l}\text { I will buy fashion product from the virtual store } \\
\text { in Instagram who has a lot of posts feed or } \\
\text { product pictures to be seen }\end{array}$ & 0.752 & 0.000 & Valid \\
\hline $\mathrm{Q}_{10}$ & $\begin{array}{l}\text { I will buy fashion product from the virtual store } \\
\text { in Instagram which has been advertised in the } \\
\text { form of Instagram Ads }\end{array}$ & 0.818 & 0.000 & Valid \\
\hline
\end{tabular}

Source: SPSS Output, prepared by writer (2018)

The result above indicates that all of the pretest sample questions (10 questions) which represent the variable of Instagram usability are valid because the $r_{\text {count }}>r_{\text {table }}$ and the significance is below than 0.1. All of the questions are considered "valid" due to its value is larger than the $r_{\text {table }}$ of 0.3061 with the significance below than 0.1 .

Table 11 Validity Test of Consumer Purchase Decision

\begin{tabular}{|c|c|c|c|c|}
\hline No & Questions & $r_{\text {count }}$ & $\begin{array}{c}\text { Sig 2 } \\
\text { tailed }\end{array}$ & Conclusion \\
\hline
\end{tabular}


Available Online at: http://ejournal.upbatam.ac.id/index.php/jim

\begin{tabular}{|c|l|c|c|c|}
\hline $\mathrm{Q}_{1}$ & $\begin{array}{l}\text { I need this fashion product because I don't have } \\
\text { it }\end{array}$ & 0.715 & 0.000 & Valid \\
\hline $\mathrm{Q}_{2}$ & $\begin{array}{l}\text { My friends said that this fashion product is } \\
\text { good }\end{array}$ & 0.757 & 0.000 & Valid \\
\hline $\mathrm{Q}_{3}$ & $\begin{array}{l}\text { I need this fashion product to accomplish my } \\
\text { activities }\end{array}$ & 0.817 & 0.000 & Valid \\
\hline $\mathrm{Q}_{4}$ & This fashion product is suitable to me & 0.720 & 0.000 & Valid \\
\hline $\mathrm{Q}_{5}$ & $\begin{array}{l}\text { I buy this fashion product because all people } \\
\text { said that this is the best seller product }\end{array}$ & 0.769 & 0.000 & Valid \\
\hline $\mathrm{Q}_{6}$ & I buy this fashion product because I love it & 0.663 & 0.000 & Valid \\
\hline $\mathrm{Q}_{7}$ & I buy this fashion product because I can have it & 0.784 & 0.000 & Valid \\
\hline $\mathrm{Q}_{8}$ & $\begin{array}{l}\text { I buy this fashion product because it fits t my } \\
\text { needs as a man/woman }\end{array}$ & 0.729 & 0.000 & Valid \\
\hline $\mathrm{Q}_{9}$ & $\begin{array}{l}\text { I buy this fashion product because I can afford } \\
\text { to buy it }\end{array}$ & 0.789 & 0.000 & Valid \\
\hline $\mathrm{Q}_{10}$ & $\begin{array}{l}\text { I buy this fashion product because my friends } \\
\text { recommended it to me }\end{array}$ & 0.942 & 0.000 & Valid \\
\hline $\mathrm{Q}_{11}$ & $\begin{array}{l}\text { I buy this fashion product because of its cheap } \\
\text { price }\end{array}$ & 0.861 & 0.000 & Valid \\
\hline $\mathrm{Q}_{12}$ & $\begin{array}{l}\text { I buy this fashion product because it comes } \\
\text { from famous virtual store account in Instagram }\end{array}$ & 0.741 & 0.000 & Valid \\
\hline
\end{tabular}

Source: SPSS Output, prepared by writer (2018)

The result above indicates that all of the pretest sample questions (12 questions) which represent the variable of consumer purchase decision are valid because the rcount > rtable and the significance is below than 0.1. All of the questions are considered to be "valid" due to its value are larger than the rtable of 0.3061 with the significance level below than 0.1 .

\begin{tabular}{|c|c|c|c|c|c|c|c|}
\hline \multicolumn{8}{|c|}{ Table 14 Linearity Test } \\
\hline & & & $\begin{array}{l}\text { Sum of } \\
\text { Squares }\end{array}$ & $\mathrm{df}$ & $\begin{array}{l}\text { Mean } \\
\text { Square }\end{array}$ & F & Sig. \\
\hline \multirow{5}{*}{$\begin{array}{l}\text { Consumer.Purchase_Decision * } \\
\text { The, Usability of Instagram }\end{array}$} & \multirow{3}{*}{$\begin{array}{l}\text { Between } \\
\text { Groups }\end{array}$} & (Combined) & 22694.290 & 44 & 515.779 & 5.577 & .000 \\
\hline & & Linearity & 17092.711 & 1 & 17092.711 & 184.819 & .000 \\
\hline & & $\begin{array}{l}\text { Deviation from } \\
\text { Linearity }\end{array}$ & 5601.578 & 43 & 130.269 & 1.409 & .104 \\
\hline & \multicolumn{2}{|c|}{ Within Groups } & 6011.429 & 65 & 92.484 & & \\
\hline & \multicolumn{2}{|c|}{ Total } & 28705.718 & 109 & & & \\
\hline
\end{tabular}

Table 12 Reliability Test

\begin{tabular}{|l|c|c|c|c|}
\hline \multicolumn{1}{|c|}{ Variable } & $\begin{array}{c}\text { Total } \\
\text { Questions }\end{array}$ & & $\begin{array}{c}\text { Cronbach's } \\
\text { Alpha }\end{array}$ & Results \\
\hline $\begin{array}{l}\text { The Usability of } \\
\text { Instagram (X) }\end{array}$ & 10 & 0.906 & Reliable \\
\hline $\begin{array}{l}\text { Consumer Purchase } \\
\text { Decision (Y) }\end{array}$ & 12 & & 0.937 & Reliable \\
\hline
\end{tabular}

Source: SPSS Output, prepared by writer (2018)

Based on the pretest sample for reliability result table above, the cronbach's alpha value variable $\mathrm{X}$ (the usability of Instagram) is 0.906 , while the cronbach's alpha value for variable $\mathrm{Y}$ (consumer purchase decision) is 0.937. This means that the questions for both variables have a perfect reliability and both of the variables are reliable because the cronbach's alpha value is bigger than 0.9 .

The analysis of the research hypothesis is as follows:

Table 13 Adjusted R Square

Model Summary

\begin{tabular}{|l|l|r|r|r|}
\hline Model & $\mathrm{R}$ & $\mathrm{R}$ Square & \multicolumn{1}{c|}{$\begin{array}{c}\text { Adjusted R } \\
\text { Square }\end{array}$} & $\begin{array}{c}\text { Std. Error of } \\
\text { the Estimate }\end{array}$ \\
\hline 1 & $.771^{\mathrm{a}}$ & .595 & .591 & 10.37157 \\
\hline
\end{tabular}


Source: SPSS Output, prepared by writer (2018)

Basically, correlation coefficients are used to measure how strong relationship is between two variables where return a value between -1 and 1 , where 1 indicates a strong positive relationship, -1 indicates a strong negative relationship, and 0 indicates no relationship at all. Based on the correlation coefficients results above, it obtains the $\mathrm{R}$ square of 0.595 , this means $59.5 \%$ of the dependent variable (consumer purchase decision) can be explained by the independent variable (the usability of Instagram), while the other $40.5 \%(100 \%$ - 59.5\%) explained by another variables which is not used in this applied research project.

$\mathrm{Y}=\mathbf{3 0 . 9 9 8}+\mathbf{0 . 8 2 2 x}$

The meaning of linear regression equation above is:

1. The value of constant 30.998 shows that if the usability of instagram is 0 or constant, then the consumer purchase decision will be in the amount of 30.998 .

2. The value of coefficient regression of instagram usability 0.822 shows that if there is any increasing value, then it will increase the value of consumer purchase decision as 0.822 , assuming the other variables are fixed.

The value of ttable sig. $<0.1$ of twotailed hypothesis test with the degree of freedom df $=108$ is 1.65895 . The result of tcount on consumer purchase decision from the t-test statistic is 12.592 with the significance value of 0.000 . It is shown that the value of tcount > ttable or $12.592>1.65909$ and significance $0.000<0.1$, thus $\mathrm{H} 1$ is accepted which means the usability of Instagram can gives a positive and significant impact towards consumer purchase decision in Medan.

According to SPSS (2015), liniearity test aims to identify and measure whether the relationship between independent variable and dependent variable is linear or not. The linearity test is a requirement in the correlation and linear regression analysis. Good research in the regression model should have a linear relationship between independent variable and dependent variable. The decision making process in the linearity test are:

1. If the value of significance from linearity $<0.1$, then the relationship between the independent variables are linearly dependent.

2. If the value of significance from linearity $>0.1$, then the relationship between independent variables with dependent is not linear.

Table 15 Regression Analysis Coefficients ${ }^{\mathrm{a}}$

\begin{tabular}{|c|c|c|c|c|c|c|c|}
\hline \multirow[t]{2}{*}{ Model } & \multicolumn{2}{|c|}{$\begin{array}{c}\text { Unstandardized } \\
\text { Coefficients }\end{array}$} & $\begin{array}{c}\text { Standardized } \\
\text { Coefficients }\end{array}$ & \multirow[b]{2}{*}{$\mathrm{t}$} & \multirow[b]{2}{*}{ Sig. } & \multicolumn{2}{|c|}{$\begin{array}{c}\text { Collinearity } \\
\text { Statistics }\end{array}$} \\
\hline & B & Std. Error & Beta & & & Tolerance & VIF \\
\hline 1 (Constant) & 30.998 & 4.776 & & 6.49 & 000 & & \\
\hline The_Usability_of_Instagram & .822 & .065 & & 12.59 & .000 & 1.000 & 1.000 \\
\hline
\end{tabular}

a. Dependent Variable: Consumer_Purchase_Decision

Source: SPPS Output, prepared by writer (2018)

Based on the ANOVA Output table, the significance from linearity of $0.000<0.1$, thus it can be concluded that there is a linear relationship between the variables of the 


\section{Available Online at: http://ejournal.upbatam.ac.id/index.php/jim}

usability of Instagram with Consumer Purchase Decision. The purpose of this research project is to confirm and ensure the influences that the independent variable "the usability of instagram" on the dependent variable "consumer purchase decision" as well as to determine the impact of independent variable towards consumer purchases decision.

Based on the result from the data analysis, $62.7 \%$ of the respondents in this research are females. Next, $100 \%$ of the total respondents are using Instagram, but only $54.5 \%$ of the respondents are active in using Instagram as their main social media platforms. Obviously, most of the Instagram users are women. Women are the one who are more often in doing shopping online especially towards fashion products. When women buy clothes, they buy identity. In addition, fashion clothing trend could be characterized as key for both reasons, firstly because of its financial esteem and also because of the social capacity implying that clothing gives them presence. Therefore, Instagram is suitable to be used by women.

Then, $88.2 \%$ of the total respondents are aged between $20-29$ years old. Hence, it is indicates that most of the Instagram users in Medan are young females, and these young females are probably will do the online purchase through Instagram. Results taken from the data analysis that $49.1 \%$ of the respondents would like to spend their time around 5-10 hours using the internet each day. Furthermore, $29.1 \%$ of the respondents spend their time using internet for browsing and chatting. Hence, it can be said that most of respondents spend their time $5-10$ hours in browsing and chatting each day. This creates an opportunity for marketers or advertisers to post an advertisement and use it as a clickbait. The advertisers can use this chance for social media marketing which refers to the process of gaining traffic or attention through social networking sites. By posting a fashion advertisement that linked to the Instagram in a browser, it will gain consumers awareness and consumers who are interested with the products may be directed to the Instagram, and this will be much more effective in marketing.

An Instagram is considered as a friendly-user application to everyone especially in sharing photos or moments through its platform. Interestingly, $49 \%$ of the respondents had done online shopping in more than 5 times based on the results of data analysis. This means that most of the respondents had done an online purchasing before and it can be said that Instagram has become the top social platform that allow its users to do a purchase online instead of being a photo-sharing application.

Based on the theory, consumer's interest to purchase a product or service always depends on the willingness to buy and at the same time have the ability to pay for the product. Results taken from data analysis, there are $64.5 \%$ respondents said that free shipping, good review, famous brand, lots of followers, product availability and cheap are the factors that motivate them to do an online purchase. Obviously, Instagram is considered to be a multifunctional application which allows its users not only to share their photos, but allow them to do an online purchase. Therefore, by having good metrics, Instagram also helps the sellers or marketers in increasing their sales and profit and expand their business through this digital era.

Next, $80 \%$ of the respondents say yes to continue for further online purchase. Therefore, it is concluded from the data analysis that most of the respondents are willing to do an online purchase through Instagram in the future because they feel benefited from it and their expectation meet their need and wants. Another possibility that may help them in continuing to do an online purchase is because nowadays, people would like to save their time and energy rather than going to the retail store to do a purchase. In fact, according to Milnes (2016), fashion retailers are increasingly using Instagram as more than a place to gain new customers, followers and likes, instead of expanding their business by having new store branches.

In terms of validity, based on SPSS Output, it stated that the pretest sample values of all of the 10 indicators of the independent variable are below the significance level of 0.1. Meanwhile to decide whether all of the indicators are considered valid is by comparing the $r_{\text {count }}$ and $r_{\text {table }}$. It is presented that if the $r_{\text {count }} \geq r_{\text {table }}$, then the $\mathrm{H}_{1}$ is accepted (valid). It is shown in the table $r$ that the value of the $r_{\text {table }}$ for the sig. twotailed distribution is 0.3061 . This means that 10 indicators in the independent variable considered being "valid". Other variable, consumer purchase decision as the dependent variable, it is shown in the SPSS Output table 


\section{Available Online at: http://ejournal.upbatam.ac.id/index.php/jim}

that those value of all 12 indicators of the variable are below the significance level of 0.1 , while the value of the $r_{\text {table }}$ for sig. two-tailed distribution is 0.3061 , this means all of the indicators are considered as "valid". For reliability test, the Cronbach's Alpha is 0.906 for the independent variable, and 0.937 for the dependent variable. Wahyuni (2014) said that if the Cronbach's Alpha is between $0.7-0.9$ means that the variable has a good reliability. Hence, as all values are falls above 0.9 , it can be said that the reliability of these data is considered to be perfect. As all data are valid and reliable, further analysis can be conducted. Instagram, the world's most popular social networking sites helps its consumers to do a social interaction with the use of words. Many of its users use it to post informations such as fashion, travel, food, art, or other subjects which can attract the consumers. Sellers and consumers can create their own account on Instagram. Not only that, sellers can create another account for selling their products or services in order to be seen by consumers. Meanwhile, with the help of technology and internet, Instagram grows into an application or platform that will influence consumers to do a purchase.

The usability of the Instagram is one of the factors that influence consumers' decision to do a purchase. By having a good metrics in the platform such as likes, comments, hashtags, followers, ads and stories, it helps in influencing consumers' decision. According to M2PressWIRE (2011), fashion industry is considered to be perfectly suited and naturally fit for social media especially Instagram. When the products are posted into the store account, consumer will see through all the posted products, and if they interested with it, they will directly contact the seller through Line or Whatsapp, and make a purchase. Having a lot of likes and comments will influences the consumer to do a purchase, however, getting a great review from the others (it might be recommended by friends, families or endorsers) will be the most effective way in influencing consumer purchase decision based on the data taken in this research. Moreover, having a great content or well-theme Instagram account, takes the second place in influencing consumer purchase decision. This means consumer would like to see more beautiful posts, well product posted in the account so that they feel attracted to see those products or services more which will lead them to do a purchase. Furthermore, when talking about hashtags, Jackson (2017) said that Instagram and hashtags are things that should be combines together, and hashtags will help the products posts to be more discoverable. However, based on the results in data analysis, using hashtags towards fashion has the least value, which means using hashtags is the least effective and efficient in influencing consumer to do an online purchase in terms of finding fashion products. Hence, recommendation from friends or family is the best way in helping consumers to do an online purchase.

Related to the theory in previous chapter, Barker (2017) presented that Instagram can be considered as a social influencers who are typically pretty well-versed on social media and will make it easier for followers to become more familiar with the brand and influence consumer to do a purchase. This means that Instagram can give such a huge impact in attracting consumers to do a purchase. There are some impacts which social media platform like Instagram can provide satisfaction to their consumers in terms of purchasing products and if they feel satisfied with the products, they will continue to do a purchase in the future. Not only satisfaction, it can provides dissatisfaction to their consumers, an if they are not satisfied after having the products, they will not continue to do a purchase with the similar store account in the future, but still there is a probability that they will do a purchase in the future, but with another store account. According to Milnes (2016), Instagram has become the top social platform where users can engage with brands especially in fashion. Despite on sharing photos with friends, Instagram can be a tool to share products or services in a form of pictures to be seen by consumers. By doing this, it will create the awareness among the consumers and it will help the store account to gain popularity. When the store account is popular, and as long as the products meet the consumer need and expectation, it will motivate consumers to do a purchase. Social media is widely used for creating brand awareness which will increase the audience reach and helps to build relationship with potential and existing customers, based on Che, Chung \& Thadani (2017). It means, social media platform like Instagram will create some virtual communities that give feedbacks or reviews by dropping 


\section{Available Online at: http://ejournal.upbatam.ac.id/index.php/jim}

some comments and likes in the store account, and this will attract consumers to do a purchase. As we can see the results of the data analysis, it is shown that most respondents would likely to buy products which is recommended by the others and has been reviewed by the others. This means that the data is supporting the statement above.

In order to determine whether Instagram can provide an impact or not, it can be seen from the data analysis where the usability of Instagram has influenced consumer purchase decision. Based on the data analysis and accompanied by $\mathrm{R}$ value, it can be concluded that Instagram has an implication towards consumer purchase decision, because the $\mathrm{R}$ value of 0.77 is considered to be very great. This value indicates that Instagram is proved to have a positive implication towards consumer purchase decision.

For the hypothesis testing, there are two hypotheses that are examined. From the tvalues obtained from the SPSS Output, it is then decided whether to accept or reject the research hypotheses. A hypothesis is accepted when the $t_{\text {count }}\left(t\right.$-value) at 0.1 significance level $>t_{\text {table }}$. Both of the hypotheses $\left(H_{0}\right.$ and $\left.H_{1}\right)$ attempt to investigate whether the independent variable "The Usability of Instagram" has an impact towards dependent variable "Consumer Purchase Decision".

For the linearity test result, it obtained from the SPSS Output, it is then decided whether the independent variable is linear towards dependent variable or not. A linearity test is considered to be linear when the significance deviation from the table is larger than the significance level of 0.1. Based on the ANOVA table, it is obtained that the value of significance linearity is 0.000 which is smaller than the significance level of 0.1 . Therefore, it can be concluded that there is linearity between independent variable and dependent variable.

The $H_{0}$ "Instagram does not give an impact towards fashion consumer purchase decision in Medan" is rejected. This result indicates that Instagram does have an impact towards consumer purchase decision in Medan. Looking the data obtained from the questionnaire, it is shown that the respondents are more likely have done their purchase online before, hence, Instagram is proved that it influences and give an impact towards consumer purchase decision.
The $H_{1}$ "Instagram does give an impact towards fashion consumer purchase deicison in Medan" is accepted. This indicates that Instagram gives impact towards consumer purchase decision. Therefore, it is true that the usability of Instagram is one of the factors that influence consumer purchase decision.

\section{CONCLUSION}

As the variables of this research is the usability of Social Networking Sites: Instagram and consumer purchase decision towards fashion in Medan, therefore the research objects are youngsters who are social media users. Long before it become the commercialized mass information and was accessible to the general public today, social networking sites (social media) were nothing back then. Today, social media has been very popular and needed as human lifestyle. Social media itself is a platform that allows people to interact, communicate, share information in the cyberspace without limitation of time and distance as long as it is connected to the Internet. In the beginning of social media development, it aims for communication between communities with particular purposes. However, its development is no longer limited to social media, but it has developed into a medium of information, communication, interaction, and even a promotion of the digital era and online business.

In 1995, social web based were established for the first time as Geocities. Geocities is a milestone of millions of other websites in the online world. The site is engaged in rental hosting to store data in the online world to be accessible to many people with the Internet. From 1997 to 1999, it created the first community social media with the name of sixdegree and classmates. While on 2002, Friendster was born which is quite popular with a wider range of users. The technology keep developing more and right in 2010, Instagram was first unleashed. Kevin Systrom and Mike Krieger, the founder of Instagram, established the photo-sharing platform that would soon

Talking about consumer purchase decision, it has been discussed that there are several ways on how Instagram give influences to it through its usability. From the discussion of this research, it is concluded that the usability of Instagram have a good relationship with consumer purchase decision because it can 


\section{JMUPB}

\section{Available Online at: http://ejournal.upbatam.ac.id/index.php/jim}

influences and give impact towards purchase decision. Therefore, the conclusion is can be made in this two statement below:

The way Instagram influences consumer purchase decision which is presented with Good Metrics - Instagram who has a great metrics which is shown in the terms of likes, comments, hashtags, ads, stories, and followers may help in giving influences towards consumer purchase decision. A lot of likes and comments from previous consumers may attract other consumers to be motivated in doing purchasing online. Instagram ads or story can help consumer in gaining more information about the products, and this may influence them to go their store account and probably will do a purchase.

In influencing consumer purchase decision an Eye Catching Content is important. By having a great content or well-themed store account will helps in giving influences towards consumers purchase decision. This will attract the eye of consumer especially when they see beautiful posts about the products. The more eye catching contents, the more consumers will visit the store account to do a purchase online.

By having good metrics, a lot of consumers who previously has done an online purchasing, can share their positive feedback or done their testimony by tagging the store account. This may helps Instagram in influencing consumers purchase decision.Based on the R-value of 0.77 , it turns out that Instagram has a positive impact towards consumer purchase decision of fashion. This can be seen by Create Awareness, Provide Satisfaction Feeling, and Create Virtual Communities.

Instagram also can provide awareness to their consumers and this helps the store account to gain popularity. This can be used by sellers, marketers or advertisers to boost consumers' awareness so that consumers will probably feel motivated to do an online purchase. This also supported by feedback and reviews. Instagram provides satisfaction to their consumers in terms of purchasing products. Hence, whenever they feel satisfied with the products, they will continue to do an online purchase in the future. Moreover, after creating awareness towards the consumer and when they feel satisfied with the products, social media platform like Instagram will create some virtual communities that give feedbacks or reviews about the products by dropping likes and comments in the store account. As the results taken from the data analysis, it is shown that most respondents in Medan would likely to buy products which have been reviewed well by the others and this kind of activity will attract consumers to do an online purchase.

By using the linear regression analysis, it can be said that the indicators of usability of Instagram can improved the consumer purchase decision by the calculation of $\mathrm{Y}=30.988+$ $0.822 \mathrm{x}$ which also means by improving on using hashtags. 


\section{Terakreditasi Nasional}

\section{Available Online at: http://ejournal.upbatam.ac.id/index.php/iim}

\section{REFERENCES}

Adminspssstatistik. (2016, May). Uji Validitas dan Realibilitas dengan SPSS. SPSS Statistik. Retrieved April 26, 2018 from the World Wide Web http://www.spssstatistik.com/ujivaliditas-dan-reliabilitas-denganspss/

Ahmad N., Salman A., \& Ashiq R. (2015). The Impact of Social Media on Fashion Industry : Empirical Investigation from Karachiites. Journal of Resources Development and Management. Vol 7, 2015. P 1-2.

Ahmed, M., (2015, May). Is Social Media the Biggest Influencer of Buying Decisions?. SocialMediaToday. Retrieved December 21, 2017 from the World Wide Web http://www.socialmediatoday.com/m arketing/masroor/2015-05-28/socialmedia-biggest-influencer-buyingdecisions

Barker, Shane. (2017, May). How Social Media Is Influencing Purchase Decisions. Social Media Week. Retrieved December 26, 2017 from the World Wide Web https://socialmediaweek.org/blog/201 7/05/social-media-influencingpurchase-decisions/

Carranza, Anthony. (2015, June). 7 Industries That Benefit Most from Social Media. SocialMediaToday. Retrieved December 14, 2017 from the World Wide Web https://www.socialmediatoday.com/s ocialnetworks/anthonycarranza/2015-0616/7-industries-benefit-most-social$\underline{\text { media }}$

Che Jasmine W. S., Cheung Christy M. K., Thadani Dimple R. (2017). Consumer Purchase Decision in Instagram Stores: The Role of Consumer Trust. Proceedings of the $50^{\text {th }}$ Hawaii International Conference on System Sciences ISBN: 978-0-9981331-0-2
$C C-B Y-N C-N D$. Retrieved December 07, 2017 from The World Wide Web URI:

http://hdl.handle.net/10125/41154

Darban, A. \& Wei, Li. (2012, June). The Impact of Online Social Networks on Consumer's Purchase Decision - The Study of Food Retailers. Jonkoping International Business School. Retrieved December 07, 2017 from the World Wide Web http://www.divaportal.org/smash/get/diva2:532049/F ULLTEXT02

Denegri-Knott, J. (2006). Consumers behaving badly: deviation or innovation? Power struggles on the web. Journal of Consumer Behaviour. Vol 5. P 8294.

Dessel, Van Gert. (2013, February). How to Determine Population and Survey Sample Size. CheckMarket. Retrieved January 22, 2018 from the World Wide Web https://www.checkmarket.com/blog/h ow-to-estimate-your-population-andsurvey-sample-size/

Dhurup, M. (2014). Impulsive Fashion Apparel Consumption: The Role of Hedonism, Fashion Involvement and Emotional Gratification in Fashion Apparel Impulsive Buying Behaviour in a Developing Country. Mediterranean Journal of Social Sciences, 5(8), 168177. Retrieved from https://doi:10.5901/mjss.2014.v5n8p $\underline{168}$

Dudovskiy, John. (2012). Convenience Sampling. Research Methodology. Retrieved February 02, 2018 from the World Wide Web https://researchmethodology.net/sampling-inprimary-data-collection/conveniencesampling/

eMarketer. (2016, March). How Social Media Influences Shopping Behaviour. eMarketer. Retrieved December 20, 2017 from the World Wide Web https://www.emarketer.com/Article/ 


\section{Terakreditasi Nasional}

Available Online at: http://ejournal.upbatam.ac.id/index.php/jim

How-Social-Media-Influences-

Shopping-Behavior/1013718

Evans, Dave., \& Mckee, Jake. (2010). Social Media Marketing: The Next Generation of Business Engagement. Canada: Wiley Publishing, Inc. Retrieved July 13, 2018 from https://www.pauladaunt.com/books/S ocial\%20Media\%20Marketing.pdf (e-book)

Fateh, Azhar (Ali). (2017, January). How Social Media Is Changing Fashion? Huffpost. Retrieved December 07, 2017 from the World Wide Web https://www.huffingtonpost.com/entr y/how-social-media-is-changingfashion us 587edd29e4b06a0baf649 $\underline{18 \mathrm{f}}$

Flekel, Alek. (2013, April). 5 Steps of Decision Making Process. Business 2 Community. Retrieved January 21, 2018 from the World Wide Web https://www.business2community.co $\mathrm{m} /$ marketing/5-steps-of-decisionmaking-process-0480178

Gallo, Amy. (2015, November 04). A Refresher on Regression Analysis. Harvard Business Review. Retrieved February 17, 2018 from the World Wide Web https://hbr.org/2015/11/a-refresheron-regression-analysis

Gebauer, Susanna. 2016. How Social Media Channels Influence Purchase Behaviour. Available at https://blog.thesocialms.com/howsocial-media-channels-influencepurchase-behavior/

Georgiou, Kiki. (2016, May). Is Instagram The Most Powerful Tool in Fashion? INDEPENDENT. Retrieved May 07, 2018 from the World Wide Web https://www.independent.co.uk/lifestyle/fashion/instagrab-is-instagramthe-most-powerful-tool-in-fashiona6996231.html

Ghozali, Imam. (2013). Aplikasi Analisis Multivariate dengan Program IBM
SPSS 21. Ed. 7, Semarang: Universitas Diponegoro.

Goldfarb, N., 2014. How Social Media Affects Fashion \& Our Buying Decisions. Available at http://wojdylosocialmedia.com/social -media-affects-fashion-buyingdecisions/

Hajli, M. Nick. (2013, January 05). A Study of the Impact of Social Media on Consumers. International Journal of Market Research Vol. 56 Issue 3. Retrieved January 31, 2018 from the World Wide Web DOI: 10.2501 /U M R-2014-025

Holmberg, J., \& Öhnfeldt, R. (2010, May). The Female Fashion Consumer Behaviour: From the Perspective of the Shop Fever in Gothenburg. Business Economic / Marketing Spring 10. Retrieved December 20, 2017 from the World Wide Web https://gupea.ub.gu.se/bitstream/2077 122658/1/gupea_2077_22658_1.pdf

Hopper, Joe, Ph.D. (2014, November). How to Label Your 10 Point Scale. VerstaResearch. Retrieved July 30, 2018 from the World Wide Web https://verstaresearch.com/blog/howto-label-your-10-point-scale/

Hudson, Matthew. (2017, September). What is Social Media? the balance. Retrieved December 22, 2017 from the World Wide Web https://www.thebalance.com/what-issocial-media-2890301

Idre (Institute for Digital Research and Education). (2017). FAQ: What Are The Differences Between One-Tailed and Two-Tailed Tests? Institute for Digital Research and Education. Retrieved April 06, 2018 from the World Wide Web https://stats.idre.ucla.edu/other/mult$\mathrm{pkg} / \mathrm{faq} / \mathrm{general} / \mathrm{faq}$-what-are-thedifferences-between-one-tailed-andtwo-tailed-tests/ 


\section{Terakreditasi Nasional}

Available Online at: http://ejournal.upbatam.ac.id/index.php/jim

Ismail, Kaya. (2017, July). The Ultimate Guide

to Content Marketing Channels: Audio \& Visual. CMS Wire. Retrieved January 31, 2018 from the World Wide Web https://www.cmswire.com/contentmarketing/the-ultimate-guide-tocontent-marketing-channels-audiovisual/

Jackson, Dominique. (2015, August). Instagram vs Facebook : Which Is Best for Your Brand. SproutSocial. Retrieved December 19, 2017 from the World Wide Web https://sproutsocial.com/insights/inst agram-vs-facebook/

Jackson, Dominique. (2017, May). 6 Instagram Metrics That Truly Measure Your Efforts. sproutsocial. Retrieved January 23, 2018 from the World Wide

Web https://sproutsocial.com/insights/inst agram-metrics/

Johnston, Euan. (2016, May). 5 Steps to Understanding Your Customer's Buying Process. B2B Marketing. Retrieved January 02, 2018 from the World Wide Web https://www.b2bmarketing.net/engb/resources/blog/5-stepsunderstanding-your-customersbuying-process

Jorgensen, Malene. (2013). Social Media Marketing Strategies B2C vs. B2B for Facebook, Twitter and Pinterest. One Door Pressed. Retrieved July 13, 2018 from

https://www.scribd.com/read/195458 496/Social-Media-Marketing-

Strategies-B2C-vs-B2B-for-

Facebook-Twitter-and-Pinterest (ebook)

Khurana, N. (2015, December). The Impact of Social Networking Sites on the Youth. Journal of Mass Communication \& Journalism 5:285, Vol. 5, Issue 12 Online ISSN-21657912. Retrieved December 07, 2017 from the World Wide Web http://dx.doi.org/10.4172/2165-

7912.1000285

Kusumah, Ryan. (2015). Analyze the Effect of Trust, Price, Quality and Perceived Risk Toward Consumer Purchase Behaviour in Online Shops Instagram. Jurnal Berkala Ilmiah Efisiensi Vol. 15 Nomor 05. Retrieved January 25, 2018 from the World Wide Web https://ejournal.unsrat.ac.id/index.ph p/jbie/article/viewFile/9843/9429

LaDuque, J. (2010, July). Get More Leads, Engage Customers With Social Media. In IFA International Franchise Association. Retrieved November 15, 2017 from the World Wide Web https://www.franchise.org/get-moreleads-engage-customers-with-social$\underline{\text { media }}$

Maina, Antony. (2017, February). 20 Popular Social Media Sites Right Now. SmallBusiness Trend. Retrieved December 26, 2017 from the World Wide Web https://smallbiztrends.com/2016/05/p opular-social-media-sites.html

Mayfield, Antony. (2008). What is Social Media? iCrossing. Retrieved July 12, 2018 from http://www.icrossing.com/uk/sites/de fault/files_uk/insight_pdf_files/What \%20is\%20Social\%20Media_iCrossin g_ebook.pdf (e-book)

Milnes, Hilary. (2016, March). The Instagram Effect: How the Platform Drives Decision at Fashion Brands. DIGIDAY. Retrieved December 26, 2017 from the World Wide Web https://digiday.com/marketing/beyon d-likes-instagram-informing-fashionbrands-internal-decisions/

Montgomery, Kathryn Ph.D., Robles, Barbara Gottlieb., Larson, Gary O. Ph.D. (2004). Center for Social Media: Youth as E-Citizens: Engaging the Digital Generation. American University. Retrieved July 10, 2018 from 


\section{Terakreditasi Nasional}

Available Online at: http://ejournal.upbatam.ac.id/index.php/jim

https://www.scribd.com/doc/1037426

/Center-For-Social-Media-Youth-As-

E-Citizens (e-book)

Moreau, Elise. (2017, December). The Top

Social Networking Sites People Are

Using. Lifewire. Retrieved

December 22, 2017 from the World

Wide Web

https://www.lifewire.com/top-socialnetworking-sites-people-are-using-

3486554

Moustakas, Evangelos. (2015, November). The Impact of Social Networking on Consumer Behaviour. Research Gate. Retrieved December 22, 2017 from the World Wide Web https://www.researchgate.net/publica tion/291691535 The impact of Soc ial Networking on consumer behav iour

M2PressWIRE. (2011). Retailers more than double their following on social media sites. (2011).M2PressWIRE, Retrieved from EBSCO host.

Nelson, Mark. (2016). Understanding Consumer Behavior: Cracking the Code of Consumer Psychology. First Edition. Retrieved July 11, 2018 from https://www.scribd.com/read/334819 806/Understanding-ConsumerBehavior-Cracking-the-Code-ofConsumer-Psychology (e-book)

Neti, S. (2011, July). Social Media and Its Role in Marketing. International Journal of Enterprise Computing and Business Systems, Vol. 1 Issue 2 ISSN (Online): 2230-8849. Retrived from http://www.ijecbs.com

Noricks, C. (2010, September 14). Advanced social media for fashion brands and Retailers. Retrieved from http://www.prcouture.com/2010/09/1 4/advanced-social-media-for-fashionbrands-retailers/

O'Cass, A. (2004). Fashion clothing consumption: antecedents and consequences of fashion clothing involvement. European Journal of
Marketing, 38(7), 869-882. Retrieved

December 31, 2017 from the World

Wide

Web

https://doi.org/10.1108/0309056041 $\underline{0539294}$

Qualman, Erik. (2009). Socialnomics : How Social Media Transforms the Way We Live and Do Business. Business Book Summaries ISBN: 978-0-470-477236. Retrieved December 20, 2017 from the World Wide Web https://www.ebscohost.com/uploads/ corpLearn/pdf/bbs_socialnomics.pdf

Raharjo, Sahid. (2015). Cara Melakukan Uji t Parsial dalam Analisis Regresi dengan SPSS. SPSS Indonesia. Retrieved May 02, 2018 from the World Wide Web https://www.spssindonesia.com/2014 /02/cara-mudah-melakukan-uji-tdengan-spss.html

Rose, S., Spinks, N. \& Canhoto, A. I. (2015). Formulae for Determining Sample Size. Management Research: Applying the Principles. Retrieved February 01, 2018 from the World Wide Web http://documents.routledgeinteractive.s3.amazonaws.com/97804 15628129/Chapter\%209\%20\%20Determining\%20sample\%20size \%20final_edited.pdf

Rouse, Margaret. (2017, May). Instagram. Whatls.com. Retrieved December 16, 2017 from the World Wide Web http://searchcio.techtarget.com/defini tion/Instagram

Rouse, Margaret. (2014, August). Facebook. Whatls.com. Retrieved December 19, 2017 from the World Wide Web http://whatis.techtarget.com/definitio $\underline{\mathrm{n} / \text { Facebook }}$

Rouse, Margaret. (2016, September). Social Networking. Whatls.com. Retrieved December 22, 2017 from the World Wide Web http://whatis.techtarget.com/definitio n/social-networking 


\section{Terakreditasi Nasional}

\section{Available Online at: http://ejournal.upbatam.ac.id/index.php/jim}

Sekaran, Uma. (2003). Research Methods for Business (A Skill Building Approach). John Wiley \& Sons, Inc ISBN 0-471-20366-1 ISBN 0-47138448-8 (WIE). Retrieved February 02, 2018 from the World Wide Web http://www.wiley.com/college

Snee, Ronald D. (2012, April). Validation of Regression Models: Methods and Examples. American Statistical Association. Retrieved February 12, 2018 from the World Wide Web http://amstat.tandfonline.com/doi/abs /10.1080/00401706.1977.10489581\#. WoFEIbM0mpo

Spark, Jane. (2016). Consumer Behaviour and Purchase Decisions. Available at http://myventurepad.com/consumerbehavior-purchase-decisions/

SPSS, brother. (2015, March). Step by Step to Test Linearity Test Using SPSS. SPSStests. Retrieved July 30, 2018 from the World Wide Web https://www.spsstests.com/2015/03/st ep-by-step-to-test-linearityusing.html

Srinagesh, Chatarajupalli. (2013, June). Leadership in Technical Institutions: A Study on Strategy and Change Management. Shodhganga : A Reservoir of Indian Thesis @INFLIBNET. Retrieved February 20, 2018 from the World Wide Web http://hdl.handle.net/10603/19730

Statistic How To. (2018). Correlation Coefficient: Simple Definition, Formula, Easy Steps. Statistic How To. Retrieved April 05, 2018 from the World Wide Web http://www.statisticshowto.com/prob ability-and-statistics/correlationcoefficient-formula/

Stephanie. (2013, August). What is a Population in Statistics? Statistic How To.
Retrieved January 22, 2018 from the World Wide Web http://www.statisticshowto.com/what -is-a-population/

TechTarget. (2011, March). Social Media Marketing (SMM). TechTarget. Retrieved January 30, 2018 from the World Wide Web http://whatis.techtarget.com/definitio $\underline{\mathrm{n} / \text { social-media-marketing-SMM }}$

Trivikram, Sujatha. (2016, December). Consumer Behaviour and Purchase Decisions. MyVenturePad. Retrieved January 02, 2018 from the World Wide Web http://myventurepad.com/consumerbehavior-purchase-decisions/

Tungate, M. (2004). Fashion brands: branding style from Armani to Zara. London: Kogan Page. ISBN 0749441089. Retrieved December 29, 2017 from the World Wide Web http://202.74.245.22:8080/xmlui/bitst ream/handle/123456789/352/Fashion + Brands+by+Mark+Tungate+.pdf?se quence $=1$

Wharton, University of Pennsylvania. 2011. Purchase Decision. Available at http://kwhs.wharton.upenn.edu/term/ purchase-decision/

Wiyani, Noor. (2014). Uji Validitas dan Realibilitas. Binus University Quality Management Center. Retrieved April 29, 2018 from the World Wide Web http://qmc.binus.ac.id/2014/11/01/uj-i-v-a-l-i-d-i-t-a-s-d-a-n-u-j-i-r-e-1-ia-b-i-l-i-t-a-s/

Yogesh, F. \& Yesha, M. (2014, May). Effect of Social Media on Purchase Decision. Pacific Business Review International Vol. 6, Issue 11. Retrieved December 15, 2017 from the World Wide Web http://www.pbr.co.in/May2014/9.pdf 